\title{
Educational ERP solutions for Higher Institutions of Learning: With an Emphasis on Human Capital Management Component
}

\author{
Tibuhinda Ngonzi* Andrew Jisaba \\ Department of Accountancy and Finance, St. Augustine University of Tanzania, P.O.Box 307 Mwanza, \\ Tanzania \\ * E-mail of the corresponding author: rigonzizk@gmail.com
}

\begin{abstract}
This paper promotes for adoption of educational enterprise resource planning systems (ERP) in the higher institutions of learning (HIL). It suggests for consideration of human capital management (HCM) as a necessary component of such ERP solutions, extending the traditional Students Management Information Systems (SMIS) and standalone financial management modules in academia. The paper is an outcome of the study involving a situational analysis of the proposal stage for educational ERP implementation, conducted at a case university in Tanzania (name withheld in consideration of ethics). Using exploratory survey, the study sought to: establish a match between the university's objectives and ERP solutions to justify for investment; understand the perception of the need among the key stakeholders; and understand the management's readiness to adopt and support such an implementation. The paper uses a new concept of 'extended Likert Scale' tool for collection of ordinal and opinion based data. Among the findings is poor customer care as an undermining factor for the currently installed SMIS performance, and a gross need for electronic HCM services that are not available. The contributions the paper makes include: exposition of the technological capabilities required to improve on knowledge and HCM in universities as required in development as well as election of educational ERP packages.
\end{abstract}

Keywords: Educational ERP, Higher Institutions of Learning, Human Capital Management, Extended Likert Scale

DOI: $10.7176 / \mathrm{IKM} / 11-4-12$

Publication date:October $30^{\text {th }} 2021$

\section{Introduction}

The UNESCO 2019 report indicates that the gross enrolment ratio in tertiary education which includes universities increased from $19 \%$ in 2000 to $38 \%$ in 2017 globally, with the female enrolment ratio exceeding the male ratio by 4 percentage points. Enrolment ratio is expressed as the number of students of a particular age group enrolled in all levels of education by the size of the population of that age group OECD (2019). The tertiary gross enrolment ratio ranges from $9 \%$ in low-income countries to $77 \%$ in high-income countries. With rapid growth rates in the $2000 \mathrm{~s}$, the report stipulates that the biggest increase in tertiary enrolment ratios is expected in middle-income countries, where it will reach 52\% by 2030 (UNESCO, 2019).

Universities in developing economies in Africa are experiencing a phenomenal outburst in enrolment as a result of demographic and economic factors. This outburst is accompanied with challenges related to heavy pressure on the carrying, administrative, infrastructural, human, and knowledge resources capacities.

Unfortunately however, it is ironical to see that universities are to a great extent featuring low in the deployment of information and communication technologies (ICT) solutions to help them handle growth challenges despite the fact that they (the challenges) are happening in the era where ICT are at an advanced stage. The studies that have so far been conducted in places such as Ghana (Sani \& Tiamiyu, 2005), Nigeria (Egoeze, Misra, Damasevicius, \& Makeliunas, 2018), Tanzania (Sife, Lwoga, \& Sanga, 2007; Swarts \& Wachira, 2010), Egypt (Soliman \& Karia, 2015a) reveal that the permeation of ICT in HIL in most developing countries is contrary to the rational expectations. This is in consideration of the institutions' IT endowment capabilities they have.

The analysis of the cited studies shows that common to the institutions are the non-integrated management information systems such as for management of student's records, admission of students, students' registration and fee payments; some library services; and websites to display universities (Egoeze et al., 2018; Krishnaveni \& Meenakumari, 2010; Sani \& Tiamiyu, 2005; Sife et al., 2007). The same studies express dissatisfaction on the use of ICT in library services automation, off-campus access to library resources, and so on. As well reported, is the low level application of computers in HIL, mostly found limited to just clerical and general administration 
functions. In that context, empirical literature is scarce on the impacts of information systems in human resources and knowledge management dimensions in universities.

Some of the identified factors for the low permeation of technology for instance to automate processes in some functions of HIL include inadequate funds (especially in private institutions which do not enjoy public funding), telecommunications connectivity (bandwidth cost and infrastructure) and inadequate human resources (Sife et al., 2007).

The effect of low permeation is lack of, or low performance in some core aspects of universities, as demonstrated through: logged complaints from users such as students on issues such as non-visibility of grades, too late dissemination of information on examination results, or other statuses; inconsistent financial information across management centres such as faculties and departments; poor information dissemination in university communities; and scarcity of knowledge management systems. This is apart from human resources functions that are almost completely forgotten.

This paper observes that information systems (IS) are among the critical success factor inputs for successful organizations in core operations performance and human resources productivity. With an emphasis on academic institutions, the paper suggests that the institutions need to be agile and flexible with information systems that have integrated data, applications, and resources across their various major units. To put it into context, information systems support business functions through automation of processes in finances, accounting, human resource management, marketing, customer services, operations, and decision making support. Accordingly the paper considers the application of enterprise systems customized to academics in HIL. This is because academics have business processes differing from other ordinary businesses. For example, the functions of sales in ordinary business my relate to fees collection in academics; where students and staff services fall in the place of customer relationship management; and others.

The observational areas in information systems research relate to either aspects of development in the cases where organizations contemplate designing the systems for their own use; or implementation where the systems are to be procured from vendors (Brehm \& Markus, 2000). In each case, the central research stages are determined as the respective systems life cycle. For the enterprise resource planning systems (ERPs) for instance, the stages are the ERP lifecycle phases, further detailed elsewhere in the sections ahead. This paper focusses on the proposition for implementation since no adoption decision is in place yet. Accordingly, its empirical scope does not include data on lifecycle phases as the IS research protocol may suggest.

Onward, the paper proceeds as follows: The next section is an overview on ERP systems, ERP systems in the context of education institutions (calling a special attention to human capital for growing universities), and ERP systems implementation foundations. This is followed by the case description and statement of the problem. The sections subsequent to that dwell on the methodology, findings and discussion, the proposal recommendation, and conclusions.

\section{Enterprise Resource Planning Systems: An Overview}

ERP systems are described as integrated information solutions that are designed to meet the information needs throughout an organization, and automation of some core business processes. In operations, it is common that when a transaction event occurs in one functional area of an organization, the same data or information is also needed in different other functional areas of the organization. For instance in an event that a student enrolls with an academic department, the details should be available to the accountancy department for billing purposes; to the students affairs department for social issues; to the registrar's office for administrative issues, and so on, and all this almost simultaneously.

ERP systems are an outcome of the integration innovation of business solutions modules such as designed for supply chain management, customer relationship management, human resources management, sales management, financial management, etc. ERP systems have evolved through at least four levels of noticeable innovations related to materials management software applications. The first application was the inventory control and management (ICM) applications in the 1960s, aimed at maintaining optimum stock levels in businesses. The ICM were improved to materials requirements planning (MRP) applications in the 1970s with features for scheduling production processes and raw materials purchases as added innovations to ICM. During the same decade the Just-in-time (JIT), another form of materials planning and control used in scheduling and purchasing of materials was invented. The two worked together very well reducing inventory management hassles and costs in manufacturing. Then was the manufacturing resources planning (MRP II) applications in the 
1980s which could handle the coordination of manufacturing processes from product planning, parts purchasing, inventory control to product distribution. ERP systems (1990s) have integrated modules for supporting marketing, finance, accounting and human resources. In addition is the Extended ERP II realized in the first decade of the 20s. This has functionalities across supply chain management, warehouse management, outbound and inbound logistics management, and the customer and supplier relationship management (CRM and SRM respectively) functions. A more detailed account of the evolution and the chronological calendar is available in literature such as the Soliman \& Karia (2015a).

In today's Information society, the management function in organizations has achieved a wide range of benefits through ERP systems such as related to cost saving, time saving, operations sufficiency, and efficiency in the utilization of fixed resources. The systems have enhanced efficacy in organizational management as well. They work through the businesses' core functional data and processes by automation of processes, for instance the provision of measurement metrics and analytical tools, and datamining among others. This is a characteristic of increasing innovative capacities of ICT, augmenting the ability to correlate pieces of information and computing power in the field of technology. The potentials of ERPs are hinged on the operation of a common database, with all other agents (people and applications) obtaining their working data form there. This ensures for continuously updated data as well as assisting easy automation of business processes.

\section{ERP in the context of educational institutions}

ERP systems are common in industrial settings. Literature on the impact of ERP is abundantly focused on addressing the integration of industry upstream activities such as management of suppliers, inbound logistics, production processes, sales \& marketing, outbound logistics, customers and customer relationship management.

Vendor ERPs as well have traditionally been standardized along those industrial processes. In such a case, the benefits are manifest through the ease with which the processes can be performed, the automation levels achievable, and the competitive advantages earned.

On the other hand, ERPs in academic settings have not been common so far. There is scarcity of evidence on the ground to show that technology has achieved a parallel consideration in the growth incidences of universities as it is in the industry of other works. However, the HIL that have implemented ERPs show a difference in their performance and scaling of academic offerings, including online and off campus services like it is for the University of Cape Town (UCT) and similar caliber universities on the continent. Krishnaveni and Meenakumar (2010) observes that in the scenarios where there is unproportioned growth between university enrolment and technology, the integration of ICT in administration functions have a potential to reduce the complexity that come with the 'tremendous' growth that is happening in higher education.

We acknowledge in this paper, as Shatat (2019, p. 3) puts it, that HIL have unique operations, complex objectives, and scattered units and authority that make it difficult to measure outputs. Equally important is looking at the factors related to the observed lagged adoption of ERP technology in HIL which call for future work. Most HIL have stopped at the Financial and Students Management Information Systems, with a conspicuous omission of human capital and knowledge management modules that this paper call for in the context of improved human capital management in HIL.

\section{Human Capital Management in Educational Institutions}

It is a fact that people and knowledge are important and value adding resources that educational organizations invest in. Like other resources, they need a careful planning, monitoring, and assessment of the value they generate for effective policies and practices. The value assessment aspect is an important factor of HCM. However, the variables to include in the assessment are in certain areas not obvious, while complex in others. The tricky thing about investing in people and knowledge resources is that there is no direct return from them like it is for machines and raw materials where return on investment can be computed with a relative ease.

Unlike in economics, where human capital is acknowledged in performance and social terms, in business the tendency is to recognize value in monetary terms so that tangible benefits can be realized. This means, the intangible values inherent in people (the knowledge, skills, and abilities (KSAs) (Baron \& Armstrong, 2007)) have to be interpreted in monetary conceptions. It therefore requests for well-defined attachments of peoples' qualities to organizational value in respective businesses on the one hand, and the mechanism for measurement in those attachments on the other. Such defined measurements are also functional in the monitoring of progress, effectiveness, and efficiency in achieving organizational goals. 
Human capital is a comprehensive term, used to conceptualize the organizational investment in people and improvement on their qualitative factors of value i.e. improvement on the KSAs. HCM focuses on the issues of planning and control practices for human capital. Telenx, a HCM software company, conceptualize HCM as "an organization's comprehensive plan and a set of practices for recruiting, managing, developing and optimizing employees to maximize their values towards an organization" (TalenX_Editorial_Team, n.d.).

This paper is anchored in Information Systems (IS) discipline. Its point of view is on establishing the links between HCM and Technology, specifically in high education settings where some aspects of, say, performance metrics need a special classification from other businesses before application. The purpose is to help in the adoption decision and acquisition stages of the educational ERP implementation lifecycle (Esteves \& Pastor, 2001; Huang \& Yasuda, 2014) in universities.

In the interests of the discussion at hand, the Afiouni (2013) definition of human capital (HC) is adopted for its wide range of conceptual reach. This is appreciated of its comprehensiveness, as it is based on a rigorous review of theoretical and empirical constructs on the essence and harnessing of HC capabilities in organizations. Human capital is the intangible value of people (Baron \& Armstrong, 2007), that practicing organizations aim to maximize. According to Afiouni (2013), HC comprises of five components: a cognitive component residing in employees as knowledge, skills and abilities; a behavioural component residing in employees willingness and ability to deploy those KSAs; a fit component residing in the alignment of the cognitive and behavioural components with strategic imperatives; a flexibility component assessing the ability for HC to adapt to different business strategies and create value at the present and future time; and finally is the measurement component assessing HC's contribution to value creation residing in the appropriateness of the alignment between the cognitive and behavioural approachs on one hand, and the strategic imperatives on the other (Afiouni, 2013, p. 27).

After that elaboration on the components of $\mathrm{HC}$, the next concept is the Human Capital Management, that is expressed by People Task Force (2003), cited in Baron and Armstrong (2007) as 'the strategic approach to management that focuses on the issues that are critical of the organization's success. Anchored on Afiouni's definition of HC, HCM takes an organization's comprehensive plan and a set of practices for the operationalization of the five dimensions of $\mathrm{HC}$ the definition is organized about.

Among the unique factors in academics is that the academic staffs in HIL forms the major faction of university human resources. They have their value vested in the knowledge they acquire/create and disseminate. This is a product, as well as a value for host organizations. Administrators in academics have to understand the complexity of managing human capital, and integrate human resources management (HRM) and knowledge management strategies in an organizational HCM strategy at large. In this sense, HCM in academics should be an enriched HRM, a factor that distinguishes the practice from other industries.

Information systems technology discipline has a space for HCM enhancement in a number of ways. First is by creating appendages to the three suggested strength areas of HCM that include: (1) the development and application of relevant qualitative and quantitative measures; (2) the gathering and interpretation of results; and (3) the decision making support in the utilization of the gathered information for strategic advantage (Baron \& Armstrong, 2007). Second should be in the measures to facilitate quality. For instance in developing tools that may enhance practices that lead to the meeting of employees' aspirations and needs, for their motivated value contribution to organizations. The two functions are in addition to the technologies that enhance a comprehensive integration of HR and human capital management (HCM) applications on a single platform.

For academics there is a specialized task of ensuring for continually knowledge up-graded staffs. Knowledge management functions have to provide for a broad data capture, handling of voluminous data, datamining, and knowledge sharing. In a nutshell, that refers to the three basic KNM activities namely: knowledge generation which describes the way employees improvise, and organizations innovate; knowledge integration - which describes how employees transform their tacit knowledge into explicit knowledge by codifying their ideas into the systems of the organization; and knowledge sharing - which describes the socialization process through which employees share knowledge with one another (Nonaka \& Takeuchi, 1995). These relate to operations such as publishing and teaching in academics.

Educational ERP systems have a great potential to enhance processes and save time (Sambhaji \& Sudhkar, 2015). Such systems can be vendor standardized to accommodate compliance processes as those identified above, as well as have features for automation, performance analytics, and alignment functionalities. The automation capabilities work to bring savings on costs and time with comprehensive workflow-driven employee and manager self-service. The measurement features help to provide metrics and analytical tools to stakeholders 
to deliver information and determine the value of different investments in HR. The alignment functionality potentially provides for performance management in a flexible manner.

\section{Modeling for the educational ERP: The logical schema}

Next to establishing the foundations for educational ERP implementation is the task of modeling. This is the activity of developing a logical framework for the system. The essence is to guide the selection at the 'adoption decision and selection' phase of the ERP lifecycle (Afiouni, 2013; Esteves \& Pastor, 2001)

We choose in this paper to adopt the HC dimensions and expected organizational outcomes as established by Afiouni (2013, p. 28) Figure 1. Then to enhance for ERP, the processes of HCM are fitted from Baron and Armstrong (Baron \& Armstrong, 2007, p. 28).

\begin{tabular}{|c|c|c|c|c|c|}
\hline $\begin{array}{r}\text { Human Capital } \\
\text { Dimensions } \\
\text { (Afiouni) }\end{array}$ & $\begin{array}{c}\text { Cognitive } \\
\text { component (Kn, } \\
\text { Skills, Abilities } \\
\text { (KSAs) }\end{array}$ & $\begin{array}{l}\text { Behavioral } \\
\text { component }\end{array}$ & Fit component & $\begin{array}{l}\text { Flexibility } \\
\text { component }\end{array}$ & $\begin{array}{l}\text { Measurement } \\
\text { component }\end{array}$ \\
\hline \multirow{4}{*}{$\begin{array}{l}\text { The process of } \\
\text { Human Capital } \\
\text { Management - } \\
\text { HCM (Baron \& } \\
\text { Armstrong) in } \\
\text { ERP }\end{array}$} & \multicolumn{5}{|c|}{ Taking Measurements } \\
\hline & \multicolumn{5}{|c|}{ Reporting the measurements } \\
\hline & \multicolumn{5}{|c|}{ Drawing conclusions about the significance of the measurements } \\
\hline & \multicolumn{5}{|c|}{ Using conclusions as a guide to future action on: } \\
\hline $\begin{array}{l}\text { Expected } \\
\text { Organizational } \\
\text { Outcomes } \\
\text { (Afiouni) }\end{array}$ & $\begin{array}{l}\text { Developing } \\
\text { critical KSAs }\end{array}$ & $\begin{array}{l}\text { Developing } \\
\text { positive behaviors } \\
\text { and attitudes } \\
\text { towards using } \\
\text { acquired KSAs }\end{array}$ & $\begin{array}{l}\text { Aligning KSAs } \\
\text { and behaviors } \\
\text { with corporate } \\
\text { objectives and } \\
\text { strategies }\end{array}$ & $\begin{array}{l}\text { Ensuring } \\
\text { continuous } \\
\text { learning and } \\
\text { adaptability of } \\
\text { different business } \\
\text { strategies }\end{array}$ & $\begin{array}{l}\text { Ensuring } \\
\text { control } \\
\text { mechanisms } \\
\text { and HC } \\
\text { contribution to } \\
\text { value creation }\end{array}$ \\
\hline
\end{tabular}

Figure 1: A blend of HC-HCM Dimensions for the logical schema of Educational ERP [Adapted from Afiouni (2013, p. 28) and Baron \& Armstrong (2007, p.28)]

Davenport (1999) cited in Baron and Armstrong (2007, p.9) explain that human capital is made of peoples 'innate abilities, behaviours and personal knowledge'. Being the owners, the people decide when, how and where to contribute it in exchange for, among others, earnings, job satisfaction, security and career prospects. In the same manner, this sits at the centre of the modelling at hand. It is here emphasized that the selection of educational ERP should not only focus on the employers' data processing outcomes, but also to include the expected benefits of employees.

In the model, the ERP functions at handling the processes of HCM, for instance in capturing and taking measurements on HC dimensions. The ERP then facilitates the other sub-processes in the HCM process. In the end, future action is focussed on the expected organizational outcomes as elaborated by Afiouni.

The data created by HCM enables organizations to know where to improve along the corporate strategy components. The measurement, analysis and evaluation is a way for promotion of the productive use of people, minimizing the guess work and subjectivity.

\section{Foundations for ERP Implementation}

Businesses implement enterprise systems to gain company-wide access to business knowledge, increase employee productivity and minimize the duplication of company data. ERP systems may also enable a business to reduce the cost of information technology and minimize the manual input of data. These enterprise systems' attributes offer particular benefits, such as the support of teamwork, an improved response to the marketplace, increased work quality, increased customer satisfaction, greater employee collaboration and efficiency. The list 
is long as informed by literature.

ERP systems are complex systems and require a rigorous lifecycle process (ERP-Lifecycle) to ensure for a successful implementation and minimal down-time during operations. Accordingly, proper planning and total support from all categories of stakeholders viz: management, employees and end-users; a clear definition of requirements, strong project team, vendor support and commitment of leadership as empirical inputs (Nirmala, Choudhary, \& Choudhary, 2013) is a critical set of success factors.

Where the implementation is to improve performance in activities such as academics, it is important to get the right system functionalities. This can only be achieved through a clear definition of requirements, and a match between requirements as an end result and the processes towards them. For instance, where a university follows a credit hours system, vendor ERPs working on pre-defined best practices may need little alignment efforts. Whereas, in the cases such as for universities that follow the 'units' approach the adaptation may be quite a demanding task (Shatat, 2019).

For implementation of an effective solution, it is advantageous to anticipate the sources of challenges. In universities, the adoption of information technologies is said to be less quick than it is for other sectors. However, it is important for the proposal stage of ERP implantation to include an investigation on the critical success factors, where an input for detailed specific implementation tactics can be enriched. This is therefore, part and parcel of implementation strategy.

System selection, integration and customization strategies depend on the organization's specific conditions that should, if identified in advance, lead to reduced failure risk.

Put together, the factors express the role of the situational analysis as an empirical input to the planning stage of the ERP-lifecycle. This is the warrant for the next part of this paper.

\section{The Case Study: Problem Background}

At her current size of 6,000 students enrolment per year, and a workforce of 500 plus, the case university, which is among the top private universities in Tanzania chosen to represent growing universities in Africa, has outgrown some of their business processes which are conducted manually. As a growing HIL it is not spared from a wide range of challenges, among them being: to survive and compete locally and globally in terms of quality and performance amidst rapid expansion and massification (Schendel \& McCowan, 2016), in an already well established industry with leaders in those aspects; and to manage content delivery amidst internet media based detractors. This is in addition to the challenges related to students' academic and non-academic services delivery management, resources management (allocation, maintenance, security etc.), human capital management (including its development, maintenance, and efficient utilization), financial and knowledge management. In a limited space of a paper like this, it is not possible to adequately explore each area mentioned sufficiently. For the purpose of promoting for educational ERP, human capital and knowledge management are selected for coverage in the assumption that the two have cross-cutting effects along other dimensions (Balán, 2012).

In that context it is in a dire need for multidimensional information flows, with at least a unified information system that cuts across functional areas such as student administration, staff administration, finances and other resources administration. The system should be looked upon to facilitate efficiency in the core business processes of the university (Figure 2). 


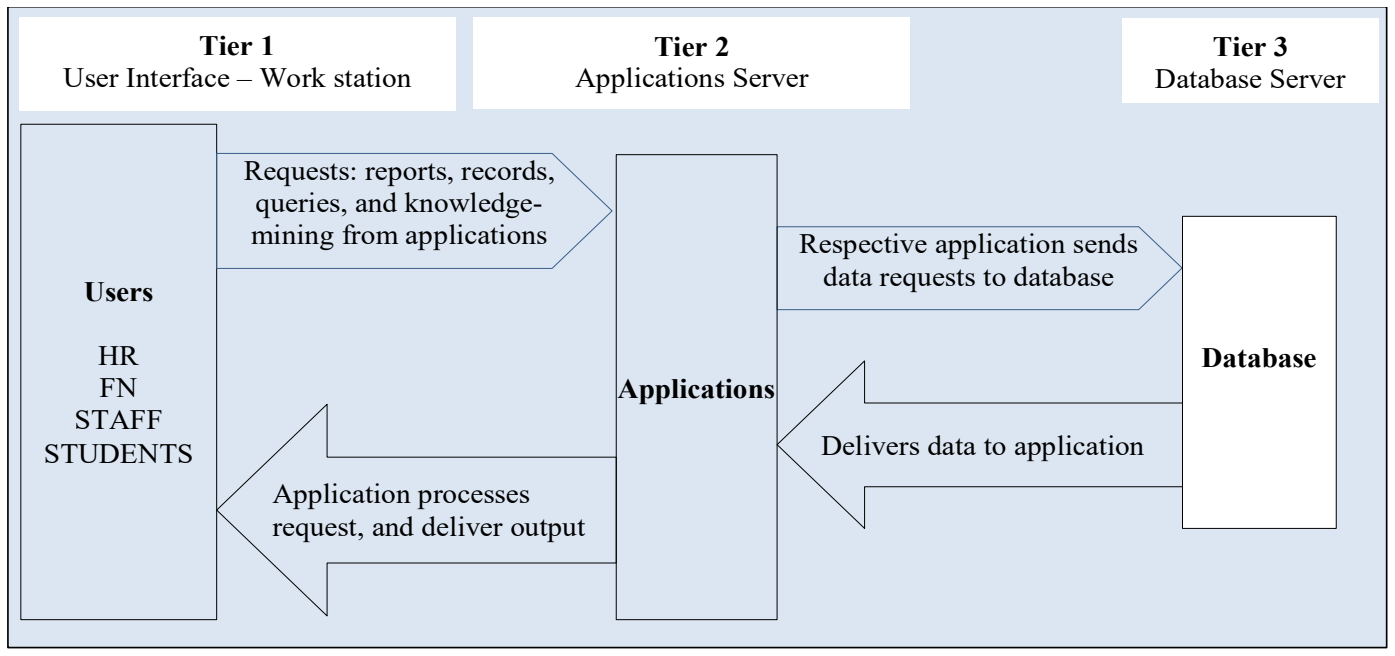

Figure 2: A 3-Tier Education ERP Architecture [Adapted from Gulla (2004)]

\subsection{Problem Statement}

The increasing trend of university enrolment in developing countries is a result of demographic drivers than economic growth. For instance, the five year (2016-2020) average population growth of Africa as per the United Nations' Department of Economic and Social Affairs-Population Division data is about $2.55 \%$ (www.worldometers.info), while the aggregate Sub-Saharan Africa per capita growth (2019) was 2.3\% (GDP per capita growth (annual \%)-Sub-Saharan Africa | Data https://data.worldbank.org > NY.GDP.PCAP.KD.ZG).

Despite focussing on private universities, empirical literature informs of the experiences in public institutions as well, where Nganga (2016, May 09) describes that "the expansion of public university facilities... has lagged behind growth in student numbers over many years".

This paper suggests part of the solution to the matter in the exploitation of technology. The sudden eruption of COVID-19 pandemic in early 2020 has catalysed a thinking on the need to have strong virtual technological capacities in universities, suggesting that it is high time the universities in the region should see the urgency of investing in technological interventions amidst the still-growing population and undergraduate education demand. Vital to that however, is that ERP solutions require effective planning and support from all stakeholders in the organizations.

The next section presents the methodology as the study continues to build a case for the technological solution through an empirical component. The questions at the centre of investigation are organized around three aspects. (1) Finding out whether the investment in ERP technology with respect to the organizational objectives is justified; (2) Probing the understanding among the key stakeholders of the university on the need for such a technological solution, and (3) Assessing the management's readiness to adopt and support the presumed deployment proposal.

\subsection{Methodology}

This study is an applied type of research. It deploys the technological protocol of ERP systems implementation projects. This is an approach where the project is sectioned in stages or phases. The stages are theoretical temporal phases that happen sequentially. A study of literature on ERP lifecycle suggests that it is not the ripe moment to take a conclusive side on the number of phases involved, as there are several propositions where this paper refers the reader to the dedicated works such as Esteves and Pastor (2001) and Huang and Yesuda (2014). In general terms however, ERP lifecycle phases can be reasonably merged in two main dimensions depending on purpose: the pre-decision making dimension which involves facts finding, business analysis and planning; and the post adoption decision phase.

The focus of this study is the pre-decision making facts finding as a prerequisite to adoption decision. It covers the situational analysis, where the need of an educational ERP (hereinafter abbreviated as edu-ERP to highlight the entitled emphasis) system for the university is examined. The business requirements, the nature of the operations and the goals and objectives of the university are carefully studied. The expected impacts of the 
solution system are as explored in the preceding literature as a prerequisite to deciding to go for its adoption. These, and the questions stated in the section above form the basis for coding in the analysis of opinion data in the questionnaire.

Going with the suggestion that it is necessary to assess the organization's readiness, management's support and IT skills required before any ERP project is undertaken (Finney \& Corbett, 2007; Law, Chen, \& Wu, 2010; Soliman \& Karia, 2015b) the paper aims at deriving a proposal for the case university management to act upon.

The population of this study consists of the administrative and academic staffs, supportive staffs and students of the case university. Information sought from each category was specific to that group, although in some cases it was common as shown in Table 1.

Table 1 Population Category Distribution

\begin{tabular}{|l|l|}
\hline Category & Information sought for an Edu-ERP \\
\hline Administrative staff & $\begin{array}{l}\text { - Feel for need as a supportive tool for administration and } \\
\text { decision making } \\
\text { - Readiness for support }\end{array}$ \\
\hline Academic staff & $\begin{array}{l}\text { - Feel for need as a supportive tool for operations } \\
- \text { feel for need as an information access facility } \\
\text { - Readiness for acceptance }\end{array}$ \\
\hline Other supportive staff & $\begin{array}{l}\text { - Feel for need as a supportive tool for operations } \\
- \text { feel for need as an information access facility } \\
\text { - Readiness for acceptance }\end{array}$ \\
\hline Students & $\begin{array}{l}\text {-Feel for need as a supportive tool for academic } \\
\text { administration. } \\
- \text { feel for need as an information access facility } \\
- \text { Readiness for acceptance }\end{array}$ \\
\hline
\end{tabular}

\subsection{Data collection}

Questionnaires were the principle data gathering tool. These were designed to capture ordinal information and expressions at the same instance using what this study refers to as 'Extended Likert scale' as shown in Tables $2 \& 3$. This was to facilitate the matching of respondents' intended rating and the qualitative implication of the rating provided. For instance item 1 on the Students' questionnaire (Rate how well are the following online services available and effective through your PC Laptop/Smart-phone etc.) would require a student to provide a rating in Table 3 using the scale provided in Table 2. Table 3 has an extra space for self-expression regarding the rating provided. In the analysis of findings, the quantitative outcome of the Likert scale is supplemented with qualitative components. This facilitates the extraction of rich information, and empirically based interpretation of the findings. The function of the extension in the scale is to capture the actual interpretation of the respondents' assigned score to the item concerned.

The items for information gathering are selected taking into consideration of the Finney and Corbett (2007) stated observation that for ERP implementations, the implementing team needs to have 'an intimate understanding' of critical success factors according to the related stakeholder groups. This is, accordingly, fundamental for the assessment of the planning phase, and the determination of the effective addressing of the concerns of the groups in question (Finney \& Corbett, 2007)

Table 2 Likert Scale

\begin{tabular}{|c|c|c|}
\hline $\begin{array}{c}1=\underset{\text { Service }}{\text { not }} \\
\text { available }\end{array}$ & $\begin{array}{c}2=\text { Service } \\
\text { available but not } \\
\text { effective }\end{array}$ & $\begin{array}{c}3=\text { Service } \\
\text { available and } \\
\text { somehow } \\
\text { effective }\end{array}$ \\
\hline
\end{tabular}

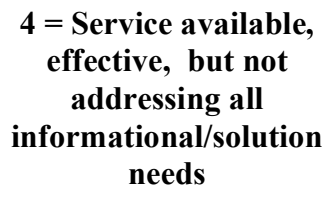

$4=$ Service available, effective, but not addressing all informational/solution needs

\section{$5=$ Service available highly effective, sufficiently addressing all informational/solution needs}

One (1) stands for "the service is completely not available". The levels 2,3 \& 4 refer to operational effectiveness levels where the service might be available, yet the experienced performance levels be deviant from expectations due to a number of factors including functionalities such as reporting and response to custom queries.

Table 3 The Sample of Rating Extension: Students' Questionnaire 
1. Rate how well are the following online services available and effective through your PC Laptop/Smart-phone etc.

\begin{tabular}{|l|l|l|l|}
\hline & Item service & Rating & $\begin{array}{l}\text { Brief explanation for the } \\
\text { rating you gave }\end{array}$ \\
\hline 1 & Online admission enquiry & & \\
\hline 2 & Online admission process & & \\
\hline 3 & Online registration and enrolment into classes and courses & & \\
\hline 4 & Online application for accommodation/hostels & & \\
\hline 5 & Online lecture notes and other learning materials & & \\
\hline 6 & Online Library services & & \\
\hline 7 & Online access to Research materials by lecturers & & \\
\hline 8 & Online Books & & \\
\hline 9 & Online Administrative enquiries & & \\
\hline 10 & $\begin{array}{l}\text { Online self-services such as printing of research approval } \\
\text { letters }\end{array}$ & & \\
\hline
\end{tabular}

\subsection{Data Analysis, Findings and Discussion}

\subsubsection{Reliability Analysis}

The Cronbach's Alpha value was used to perform the reliability / internal consistency assessment of the items on the question related to availability and effectiveness of e-services. This was important because the test items used all reflect on the common factor, an Information System in the organization if any. The Alpha values obtained are listed in Table 4 , where various literature describe values $\geq 0.70$ as generally acceptable, while $\leq 0.59$ is unacceptable, and 0.60 to 0.69 shows weak consistency but usable (Santos, 1999; Taber, 2018; Tavakol \& Dennick, 2011; Vaske, Beaman, \& Sponarski, 2017).

Table 4 Reliability Statistics

\begin{tabular}{|l|c|}
\hline Category of respondents & Cronbach's Alpha \\
\hline Students & 0.655 \\
\hline $\begin{array}{l}\text { Department Heads and } \\
\text { Faculty Deans }\end{array}$ & 0.934 \\
\hline $\begin{array}{l}\text { Administrative and } \\
\text { support Staffs }\end{array}$ & 0.958 \\
\hline Academic Staff & 0.709 \\
\hline
\end{tabular}

\subsubsection{Data Analysis}

Tables $5 \& 6$ below summarise the empirical observations related to the matching of the proposal ERP with university objectives. They project the services situation at hand. Table 6 is an output of the free version of QDA Miner LITE qualitative data analysis software. Table 8 summarizes the responses regarding the felt need for an ERP solution among the stakeholders, and the management's readiness to support a solution like that.

1. Matching of technology to university objectives: Finding out whether the investment in ERP technology with respect to the organizational objectives is justified

For the objectives of the university, a technological solution is essential as a push and facilitation tool. The university objectives whose the first is "to form an academic community as a centre of creativity and dissemination of knowledge.." where the community in point "is made up of both teachers and learners..", derive from the University's mission statement importantly articulated as, among other things, "the University strives to promote the pursuit and defence of truth, transparency, honesty, service with competence and devotion".

The administration needs to understand technology as a driver to achieving effective and transparent administration, information dissemination and sharing, as well as a handler of operations.

Corporate wide information access by employees helps members to interact easily and on equal terms. This in turn builds into facilitation of knowledge sharing and creation through socialization. 
A technological solution could help to have in-built structures transparent to all staffs for decision making, e.g. for leave scheduling, sabbatical leave dues and qualifiers, promotion qualifiers, etc.

\section{Observations}

Table 5 presents a summary of the SPSS 20 computed means of the Likert-Scale Scores. In the columns are the respondent categories, while the rows capture the questionnaire items responded to. The means are respectively, the mean score on the items, and at the bottom of the table is the overall mean for each respondent's category.

The bolded entries are those with the mean scores between 3.00 and 3.50. The highest happens to fall in this space, indicating that none of the available services can address all informational/solution needs in the institution. The rest are, unfortunately below effectiveness levels.

On the 'Overall means' row, it is observed that scores are below 3.00 for every stakeholders category. This is in general a poor Information Systems services situation at the case institution.

In the analysis of text data (Table 6), the main factors emerging from the coding of text data are related to the performance of the currently existing information system, issues with technology infrastructure, Systems administration, lack of technological capacity such as the appropriate software to handle the service, and HCM related functionings.

The existing is just a Students Management Information System (SMIS) whose failure to perform is attributable to poor customer care and frequent network down time. In broader terms, the SMIS is limited on capacity to support the functions of knowledge management, HCM, and other online services. To serve space, other factors are as visible in the Table 6 itself.

A general observation on the question is that, in the current state of technology and infrastructure the University's objectives in general terms cannot be effectively achieved.

Table 5 Summary of Likert-Scale Mean Scores on Information Systems Services Availability

\begin{tabular}{|c|c|c|c|c|c|c|c|c|c|c|}
\hline \multirow[t]{3}{*}{ 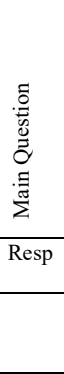 } & \multirow{2}{*}{\multicolumn{2}{|c|}{$\begin{array}{l}\text { Rate how well are the } \\
\text { following online services } \\
\text { available and effective } \\
\text { through your PC } \\
\text { (Laptop/Smart-phone etc.) } \\
\text { Students }\end{array}$}} & \multicolumn{8}{|c|}{$\begin{array}{l}\text { Rate how satisfied you are with the extent to which the functions in the table are available electronically through } \\
\text { the University's existing Information Systems. }\end{array}$} \\
\hline & & & $\begin{array}{l}\text { Heads of Dep } \\
\text { and Deans of Fa }\end{array}$ & $\begin{array}{l}\text { tments } \\
\text { lties }\end{array}$ & Administrative & & Support Staff & & Academic Staff & \\
\hline & Items & $\begin{array}{l}\text { Mea } \\
\mathrm{n} \\
\text { score }\end{array}$ & Items & $\begin{array}{l}\text { Mea } \\
\mathrm{n} \\
\text { score }\end{array}$ & Items & $\begin{array}{l}\text { Mean } \\
\text { score }\end{array}$ & Items & $\begin{array}{l}\text { Mea } \\
\mathrm{n} \\
\text { score }\end{array}$ & Items & $\begin{array}{l}\text { Mea } \\
\mathrm{n} \\
\text { score }\end{array}$ \\
\hline 1 & $\begin{array}{l}\text { 'Online admission } \\
\text { enquiries' }\end{array}$ & 2.51 & $\begin{array}{l}\text { Availability of } \\
\text { a planning } \\
\text { template for } \\
\text { department }\end{array}$ & 2.67 & $\begin{array}{l}\text { Availability of } \\
\text { a facility for } \\
\text { Strategic } \\
\text { planning and } \\
\text { performance } \\
\text { management }\end{array}$ & 1.67 & $\begin{array}{lr}\text { Facility } & \text { for } \\
\text { Access } & \text { to } \\
\text { personal } & \\
\text { records } & \end{array}$ & 3.00 & $\begin{array}{lr}\text { Facility } & \text { for } \\
\text { lecture notes } \\
\text { and other } \\
\text { learning/teachin } \\
\mathrm{g} \text { materials } \\
\text { upload and } \\
\text { download to } \\
\text { common } \\
\text { university drive }\end{array}$ & 2.33 \\
\hline 2 & $\begin{array}{l}\text { Online admission } \\
\text { process }\end{array}$ & 3.73 & $\begin{array}{l}\text { Availability of } \\
\text { office duties } \\
\text { scheduling } \\
\text { facility }\end{array}$ & 2.33 & $\begin{array}{l}\text { Financial } \\
\text { Management } \\
\text { eg budgeting } \\
\text { and controls }\end{array}$ & 2.00 & $\begin{array}{ll}\text { Facility for } \\
\text { Online } \\
\text { updates on } \\
\text { personal } \\
\text { record } & \\
\end{array}$ & 2.25 & $\begin{array}{l}\text { Facility for } \\
\text { Online } \\
\text { management of } \\
\text { classes }\end{array}$ & 1.33 \\
\hline 3 & $\begin{array}{l}\text { Online registration } \\
\text { and enrolment into } \\
\text { classes and courses }\end{array}$ & 2.81 & $\begin{array}{l}\text { Availability of } \\
\text { attendance } \\
\text { supervision } \\
\text { facility }\end{array}$ & 2.33 & $\begin{array}{l}\text { Access/ } \\
\text { Maintenance } \\
\text { of staff records }\end{array}$ & 1.67 & $\begin{array}{l}\text { Facility for } \\
\text { Online } \\
\text { Performance } \\
\text { appraisal }\end{array}$ & 1.75 & $\begin{array}{l}\text { Facility for } \\
\text { Online peer } \\
\text { communication }\end{array}$ & 1.00 \\
\hline 4 & $\begin{array}{l}\text { Online application for } \\
\text { accommodation/hostel } \\
\text { s }\end{array}$ & 2.85 & $\begin{array}{l}\text { Availability of } \\
\text { a Monitoring } \\
\text { and evaluation } \\
\text { functions } \\
\text { handling } \\
\text { facility }\end{array}$ & 2.33 & $\begin{array}{l}\text { Access/ } \\
\text { Maintenance } \\
\text { of Materials/asset } \\
\text { s records } \\
\text { including } \\
\text { purchases, } \\
\text { innovations, } \\
\text { inventory etc. }\end{array}$ & 1.83 & $\begin{array}{l}\text { Facility for } \\
\text { Online } \\
\text { transactions eg } \\
\text { communicatio } \\
\mathrm{n} \quad \text { with } \\
\text { administration }\end{array}$ & 1.75 & $\begin{array}{l}\text { Facility for } \\
\text { Access to } \\
\text { academic/non- } \\
\text { academic staff } \\
\text { research } \\
\text { materials }\end{array}$ & 2.67 \\
\hline
\end{tabular}




\begin{tabular}{|c|c|c|c|c|c|c|c|c|c|c|}
\hline 5 & $\begin{array}{l}\text { Online lecture notes } \\
\text { and other learning } \\
\text { materials }\end{array}$ & 1.87 & $\begin{array}{l}\text { Availability of } \\
\text { the Staff work } \\
\text { Evaluation } \\
\text { facility }\end{array}$ & 4.00 & $\begin{array}{l}\text { Facility for } \\
\text { Staff } \\
\text { recruitment }\end{array}$ & 2.83 & $\begin{array}{l}\text { Facility for } \\
\text { Computer } \\
\text { skills } \\
\text { advancement }\end{array}$ & 2.75 & $\begin{array}{l}\text { Facility for SW } \\
\text { Applications } \\
\text { e.g. qualitative } \\
\text { and quantitative } \\
\text { data analysis } \\
\text { software }\end{array}$ & 1.33 \\
\hline 6 & $\begin{array}{l}\text { Online } \quad \text { Library } \\
\text { services }\end{array}$ & 1.40 & $\begin{array}{l}\text { Availability of } \\
\text { a Performance } \\
\text { appraisal } \\
\text { facility }\end{array}$ & 3.67 & $\begin{array}{l}\text { Facility for } \\
\text { Work } \\
\text { allotment }\end{array}$ & 2.50 & $\begin{array}{l}\text { Facility for } \\
\text { accomplishin } \\
\text { g Routine } \\
\text { work through } \\
\text { computer }\end{array}$ & 3.00 & $\begin{array}{lr}\text { Facility } & \text { for } \\
\text { Resources } & \\
\text { sharing e.g. } \\
\text { printer/scanner/ }\end{array}$ & 3.00 \\
\hline 7 & $\begin{array}{l}\text { Online access to } \\
\text { Research materials by } \\
\text { lecturers }\end{array}$ & 1.94 & $\begin{array}{l}\text { Students } \\
\text { management } \\
\text { facility for } \\
\text { Students } \\
\text { affairs eg } \\
\text { communication } \\
\text { enquiries, } \\
\text { handling } \\
\text { queries }\end{array}$ & 3.67 & $\begin{array}{l}\text { Facility for } \\
\text { Attendance } \\
\text { and leave } \\
\text { management }\end{array}$ & 2.00 & $\begin{array}{l}\text { Facility for } \\
\text { Work } \\
\text { collaboration } \\
\text { through } \\
\text { computer }\end{array}$ & 2.5 & $\begin{array}{l}\text { Facility for } \\
\text { Online } \\
\text { performance } \\
\text { appraisal }\end{array}$ & 1.00 \\
\hline 8 & $\begin{array}{l}\text { Online access to } \\
\text { e-Books }\end{array}$ & 2.33 & $\begin{array}{l}\text { Academic } \\
\text { affairs } \\
\text { handling } \\
\text { facility }\end{array}$ & 3.33 & $\begin{array}{l}\text { Facility for } \\
\text { Payroll, } \\
\text { allowances } \\
\text { and others }\end{array}$ & 3.00 & $\begin{array}{l}\text { Facility for } \\
\text { Access and } \\
\text { check on } \\
\text { standards } \\
\text { related to } \\
\text { performance } \\
\text { of your work }\end{array}$ & 2.25 & $\begin{array}{l}\text { Facility for } \\
\text { Online access } \\
\text { and updates on } \\
\text { personal records } \\
\text { e.g. CV }\end{array}$ & 1.33 \\
\hline 9 & $\begin{array}{l}\text { Online Administrative } \\
\text { enquiries }\end{array}$ & 2.18 & $\begin{array}{l}\text { A facility for } \\
\text { handling of } \\
\text { Administrative } \\
\text { affairs e.g. } \\
\text { allocation of } \\
\text { courses etc. }\end{array}$ & 3.00 & $\begin{array}{lr}\text { Facility } & \text { for } \\
\text { Checking } & \text { on } \\
\text { dues } & \text { and } \\
\text { advances } & \\
\text { related } & \text { to } \\
\text { students } & \end{array}$ & 2.83 & $\begin{array}{l}\text { Facility for } \\
\text { Access and } \\
\text { check on } \\
\text { strategic } \\
\text { performance }\end{array}$ & 2.25 & $\begin{array}{l}\text { Facility for } \\
\text { Access to } \\
\text { research } \\
\text { materials by } \\
\text { other lecturers }\end{array}$ & 2.00 \\
\hline 10 & $\begin{array}{l}\text { Online self-services } \\
\text { such as print of } \\
\text { research approval } \\
\text { letters }\end{array}$ & 1.49 & $\begin{array}{l}\text { A facility for } \\
\text { handling } \\
\text { Financial } \\
\text { affairs e.g. } \\
\text { departmental } \\
\text { budget } \\
\text { management }\end{array}$ & 2.00 & $\begin{array}{l}\text { Facility for } \\
\text { Checking on } \\
\text { dues/ arears/ } \\
\text { advances etc. } \\
\text { related to staff }\end{array}$ & 2.50 & & & $\begin{array}{l}\text { Facility for } \\
\text { Access to } \\
\text { library services } \\
\text { while off-site }\end{array}$ & 1.67 \\
\hline 11 & $\begin{array}{l}\text { Online exam records } \\
\text { availability }\end{array}$ & 4.03 & $\begin{array}{l}\text { A facility for } \\
\text { Strategy } \\
\text { performance } \\
\text { monitoring }\end{array}$ & 2.00 & $\begin{array}{lr}\text { Facility for } \\
\text { Checking on } \\
\text { Dues/ arears/ } \\
\text { advances etc. } \\
\text { related to } \\
\text { suppliers of } \\
\text { various service } \\
\text { including } \\
\text { contractors }\end{array}$ & 2.17 & & & $\begin{array}{l}\text { Facility for } \\
\text { Online } \\
\text { transactions e.g. } \\
\text { communication } \\
\text { with } \\
\text { administration }\end{array}$ & 2.67 \\
\hline 12 & & & $\begin{array}{l}\text { A facility for } \\
\text { Maintenance } \\
\text { of staff } \\
\text { records }\end{array}$ & 3.00 & $\begin{array}{l}\text { Facility for } \\
\text { Financial } \\
\text { expenses } \\
\text { monitoring }\end{array}$ & 2.17 & & & & \\
\hline 13 & & & $\begin{array}{l}\text { A facility for } \\
\text { Maintenance } \\
\text { of students } \\
\text { records }\end{array}$ & 3.00 & $\begin{array}{l}\text { Facility for } \\
\text { Staff } \\
\text { Performance } \\
\text { appraisal }\end{array}$ & 2.67 & & & & \\
\hline 14 & & & $\begin{array}{l}\text { A Decision } \\
\text { making } \\
\text { support facility }\end{array}$ & 2.00 & & & & & & \\
\hline 15 & & & $\begin{array}{l}\text { A facility for } \\
\text { Routine } \\
\text { communication }\end{array}$ & 2.33 & & & & & & \\
\hline $\begin{array}{l}\text { O/Mea } \\
\text { n }\end{array}$ & Students & $\begin{array}{l}2.46 \\
6\end{array}$ & HoD/Deans & $\begin{array}{l}2.77 \\
7\end{array}$ & Admin & $\begin{array}{l}2.29 \\
5\end{array}$ & Support Staff & $\begin{array}{l}2.35 \\
0\end{array}$ & Academic & $\begin{array}{l}1.90 \\
0\end{array}$ \\
\hline
\end{tabular}




\begin{tabular}{|c|c|c|}
\hline & Count & $\%$ Codes \\
\hline \multicolumn{3}{|l|}{$\forall$ \& Performance } \\
\hline$\bullet$ Service improvement requested & 35 & $10,7 \%$ \\
\hline - Service Unavailability complained & 25 & $7,6 \%$ \\
\hline - Improve on existing System & 56 & $17,1 \%$ \\
\hline - Inadequate access to, and availability of information & 31 & $9,5 \%$ \\
\hline Gross dissatisfaction & 4 & $1,2 \%$ \\
\hline - Poor service delivery & 10 & $3,1 \%$ \\
\hline \multicolumn{3}{|l|}{ Infrastructural Issues } \\
\hline$\bullet \mathrm{HW} /$ Network/Functioning & 17 & $5,2 \%$ \\
\hline \multicolumn{3}{|l|}{ \$ Systems Administration } \\
\hline Unreliable services and operations & 9 & $2,8 \%$ \\
\hline Customer care services eg. guidance & 13 & $4,0 \%$ \\
\hline \multicolumn{3}{|l|}{ \& Lack of Technical Capacity for the functinon } \\
\hline - Requests for absent Technological capabilities & 60 & $18,3 \%$ \\
\hline - Information sharing lacking & 9 & $2,8 \%$ \\
\hline - Support for online services requested & 26 & $8,0 \%$ \\
\hline \multicolumn{3}{|l|}{ \&uman resources management Issues } \\
\hline$\bullet \mathrm{HR}$ information services & 6 & $1,8 \%$ \\
\hline - Services integration factors & 11 & $3,4 \%$ \\
\hline - University objectives affected & 3 & $0,9 \%$ \\
\hline \multicolumn{3}{|l|}{ \& Positive comments } \\
\hline - Service satisfactory & 12 & $3,7 \%$ \\
\hline
\end{tabular}

2. Probing the understanding among the key stakeholders of the university on the need for ERP technological solution

On assessing of how the institution's stakeholders perceive the need for the technology solution that is able to address the limitations experienced in the current processes there were four items for the respondents.

The Likert scale used had five levels, ranging from $1=$ very low, to $5=$ very highly. Table 7 presents the summary of the mean scores to the scale. 
Table 7: Summary of Likert-Scale Mean Scores on the Information Systems Services need perception among the Stakeholders

\begin{tabular}{|c|c|c|c|c|c|}
\hline & \multicolumn{5}{|c|}{ Mean Scores by respondents category } \\
\hline STAKEHOLDERS & $\begin{array}{l}\text { Students } \\
\mathrm{N}=268\end{array}$ & $\begin{array}{l}\text { Department } \\
\text { Heads/Faculty } \\
\text { Deans N-23 }\end{array}$ & $\begin{array}{l}\text { Administration } \\
\text { Staff } \\
\text { N=10 }\end{array}$ & $\begin{array}{l}\text { Support } \\
\text { Staff } \\
\mathbf{N}=\mathbf{5 0}\end{array}$ & $\begin{array}{l}\text { Academic } \\
\text { Staff } \\
\text { N=152 }\end{array}$ \\
\hline $\begin{array}{l}\text { 1. Do you feel any need for the } \\
\text { technology that can facilitate the } \\
\text { functions above after your } \\
\text { ratings? }\end{array}$ & 4.65 & 4.33 & 5.00 & 4.50 & 4.67 \\
\hline $\begin{array}{l}\text { 2. To what extent are you ready } \\
\text { to avail any administrative } \\
\text { support for the implementation of } \\
\text { a technology/ a system that can } \\
\text { address the functions you have } \\
\text { rated in the table? }\end{array}$ & N.A & 4.33 & 4.80 & 4.25 & 4.67 \\
\hline $\begin{array}{l}\text { 3. To what extent are you ready } \\
\text { to budget for the implementation } \\
\text { of a technology/ a system that } \\
\text { can address the functions you } \\
\text { have rated in the table? }\end{array}$ & N.A & 4.33 & 4.67 & 4.00 & 4.67 \\
\hline $\begin{array}{l}\text { 4. To what extent do you think a } \\
\text { system designed to support the } \\
\text { functions you have rated in the } \\
\text { table will facilitate the achieving } \\
\text { of the University's objectives? }\end{array}$ & 4.46 & 4.33 & 5.00 & 4.67 & 4.67 \\
\hline
\end{tabular}

Observations from the table above indicate a high enthusiasm for the technological solution. This warrants for the contemplated educational ERP which can effectively and efficiently integrate functions. The administrative support is very high [above 4.5] in all variables (see column 4). Currently there is nothing beyond the SMIS, and a financial package. Applications of the category of 'PeopleSoft' for instance are likely to change the state of affairs.

\section{Assessing the management's readiness to adopt and support the presumed solution proposal}

On Table 7 again, the 'Administrative staffs are the key decision makers. Their scores on items 2,3, \& 4 indicate their support and readiness to the solution proposal. These ranges from 4.67 to 5.00: Very highly.

Accordingly, a motivation for the technological solution is justified.

In summary, the findings are interpreted into three dimensions.

1) Operational requirements:

- Capture of data such as recording of attendance, enquiries, etc.

- Making measurements such as quantitative and qualitative achievements

- Keeping paperwork to the minimum

2) Informational requirements

- Handling of queries

- Response to queries

- General information needs

The staffs have no any facility of electronic nature for inquiry of any kind. 
3) Decision making and decision support functions

- OPRAS and promotion matters

- Staff development matters

- Staff leaves matters

- Remuneration matters such as allowances, gratuity etc.

As a recommendation, there is a need for a planned data capture, allocated resources for data management, and to have proper applications in place for enhancing data querying and information access.

\section{CONCLUSIONS}

The work of this paper was to motivate for the adoption of educational ERP in the higher institutions of learning. This comes from the observations from literature that higher institutions of learning tend to concentrate and end at the installation of Students' management information systems which lack capabilities to handle knowledge and human capital management issues. This undermines the realization of the general as well as the specific HIL's objectives which tend to be similar globally.

The paper exploited a blend of Baron \& Armstrong (2007) human capital dimensions and Afiouni (2013) human capital management measurements to express a sample of the processes functional in a proposed educational ERP.

The paper introduced the use of 'Extended Likert Scale' concept to capture ordinal and opinion data in the conducting of the situational analysis which followed the ERP lifecycle protocol. The analysis aimed at answering questions on the whether the proposal was justified with respect to the case university objectives, the stakeholders' perception for the need of the technology, and the management's readiness to adopt and support the technology solution.

The paper notices a high need for the proposed solution. Despite there being a students' MIS, yet there is dissatisfaction in the online services accessibility and effectiveness: a factor that is attributed to poor customer care and network problems. The staffs at all levels, including the administration, express a very high need for information systems components to handle their contractual matters. However, investigating the factors that have hindered the management from initiating a move to invest in such a solution, despite the expressed need and readiness to support was out of the scope of this paper. It remains to be the work of the future.

\section{References}

Afiouni, F. (2013). Human capital management: A new name for HRM? International Journal of Learning and Intellectual Capital, 10(1), 18-34. https://doi.org/10.1504/IJLIC.2013.052081

Balán, J. (2012). Research Universities in Latin America: The Challenges of Growth and Institutional Diversity. Social Research, 79(3), 741-770.

Baron, A., \& Armstrong, M. (2007). Human capital management: Achieving added value through people. London: Kogan Page Ltd.

Brehm, L., \& Markus, M. L. (2000). The Divided Software Life Cycle of ERP Packages. In Proceedings of the 1st Global Information Technology Management (GITM) World Conference Memphis, June 11- 13 2000. (pp. 43-56). Tennessee, USA.

Egoeze, F., Misra, S., Damasevicius, R., \& Makeliunas, R. (2018). Impact of ICT on Universities Administrative Services and Management of Students' Records: ICT in University Administration. International Journal of Human Capital and Information Technology Professionals, (April).

Esteves, J., \& Pastor, J. (2001). Enterprise Resource Planning Systems Research: An Annotated Bibliography. Communications of the Association for Information Systems, 7(8), 1-51.

Finney, S., \& Corbett, M. (2007, June 12). ERP implementation: A compilation and analysis of critical success factors. Business Process Management Journal. https://doi.org/10.1108/14637150710752272

Gulla, J. A. (2004). Introduction to Enterprise Systems.

Huang, T., \& Yasuda, K. (2014). ERP Life Cycle Models: An Annotated Bibliographic Review. Proceedings of the Asia Pacific Industrial Engineering \& Management Systems Conference. Retrieved from 
https://www.researchgate.net/publication/289518675

Krishnaveni, R., \& Meenakumari, J. (2010). Usage of ICT for Information Administration in Higher education Institutions - A study. International Journal of Environmental Science and Development, 1(3), 282-286.

Law, C. C., Chen, C. C., \& Wu, B. J. (2010). Managing the full ERP life-cycle: Considerations of maintenance and support requirements and IT governance practice as integral elements of the formula for successful ERP adoption. Computers in Industry, 61(3), 297-308. https://doi.org/10.1016/j.compind.2009.10.004

Lockwood, G., Davies, J., \& Society for Research into Higher Education (Great Britain) (1985). Universities: the management challenge. Society for Research into Higher Education; Windsor, Berkshire; Philadelphia, PA : NFER-NELSON, [Guildford, Surrey]

Nirmala, K., Choudhary, R., \& Choudhary, J. R. (2013). ERP implementation issues in Higer Educational Institutes with specific reference to Pune Region. International Journal Information Tachnology \& Management Information Systems (IJITMIS), 4(2), 31-39.

Nonaka, I., \& Takeuchi, H. (1995). The knowledge-creating company: How Japanese companies create the dynamics of innovation.

Sambhaji, D. B., \& Sudhkar, B. D. (2015). Impact of ICT in a Univesity Office Administration System. International Journal of Engineering and Management Sciences, 6(2), 52-56.

Sani, A., \& Tiamiyu, M. (2005). Evaluation of automated services in Nigerian universities. Electronic Library. https://doi.org/10.1108/02640470510603679

Santos, J. R. . (1999). Cronbach's alpha: A tool for assessing the reliability of scales. Journal of Extension, 37(2), 1-5. Retrieved from https://www.joe.org/joe/1999april/tt3.php?vm=r

Schendel, R., \& McCowan, T. (2016). Expanding higher education systems in low- and middleincome countries: the challenges of equity and quality. High Educ, 72, 407-411. https://doi.org/10.1007/s10734-016-0028-6

Shatat, A. S. (2019). The Impact of ERP System on Academic Performance : Journal of Information \& Knowledge Management, 18(2), 18. https://doi.org/10.1142/S0219649219500187

Sife, A. S., Lwoga, E. T., \& Sanga, C. (2007). New technologies for teaching and learning: Challenges for higher learning institutions in developing countries. International Journal of Education and Development Using Information and Communication Technology (IJEDICT), 3(2), 57-67.

Soliman, M., \& Karia, N. (2015a). Enterprise Resource Planning ( ERP ) System as an Innovative Technology in Higher Education Context in Egypt. International Journal of Computing Academic Research (IJCAR), 4(5), 265-269.

Soliman, M., \& Karia, N. (2015b). Higher Education Competitive Advantage : Enterprise Resource Planning Systems. IRACST - International Journal of Research in Management \& Technology, 5, 2249-9563.

Swarts, P., \& Wachira, E. M. (2010). Tanzania: ICT in Education situational analysis. Retrieved from http://creativecommons.org/licenses/by-nc-sa/3.0/

Taber, K. S. (2018). The Use of Cronbach's Alpha When Developing and Reporting Research Instruments in Science Education. Research in Science Education, 48(6), 1273-1296. https://doi.org/10.1007/s11165-016-96022

TalenX_Editorial_Team. (n.d.). Human Capital Management(HCM) : Definitions, Benefits \& Reviews 2020. Retrieved May 18, 2020, from https://talenx.io/2019/11/21/what-is-human-capital-management/

Tavakol, M., \& Dennick, R. (2011). Making sense of Cronbach's alpha. International Journal of Medical Education, 2, 53-55. Retrieved from http://creativecommons.org/licenses/by/3.0/

UNESCO. (2019). Meeting commitments: Are countries on track to achieve SDG4? Retrieved from http://uis.unesco.org/sites/default/files/documents/meeting-commitments-are-countries-on-track-achievesdg4.pdf

Vaske, J. J., Beaman, J., \& Sponarski, C. C. (2017). Rethinking Internal Consistency in Cronbach's Alpha. Leisure Sciences, 39(2), 163-173. https://doi.org/10.1080/01490400.2015.1127189 
Tibuhinda Ngonzi (Ph.D.)* is a lecturer in the department of Accountancy and Finance of St Augustine University of Tanzania. He acquired his qualifications from the Universities of Dar- es Salaam (Tanzania), Goa (India), Uganda Martyrs (Uganda) and Cape Town (SA). His areas of specialty include Information Systems and Finance, with research interests in the fields of social innovation, ICT4D, digital divide and Capital structure. His existing publications cover the same respective areas.

Mr. Andrew Jisaba is an Assistant lecturer in the department of Accountancy and Finance of St Augustine University of Tanzania. He studied at the University of Dar-Es-Salaam in Tanzania, and the University of Strathclyde U.K. His research interests are in Information technology and Investments. 